Dokuz Eylül Üniversitesi-Mühendislik Fakültesi

Fen ve Mühendislik Dergisi

Cilt 20, Sayı 60, Eylül, 2018
Dokuz Eylul University-Faculty of Engineering Journal of Science and Engineering Volume 20, Issue 60, September, 2018

DOI: $10.21205 /$ deufmd. 2018206059

\title{
Amasya Değirmendere Barajında Sulama Alanı ve Baraj Yüksekliği Arasında Ekonomik Analiz
}

\author{
Aslı ÜLKE KESKINN*, Şuayip Deniz DEMİR² \\ 1 Ondokuz Mayıs Üniversitesi, Mühendislik Fakültesi, İnşaat Mühendisliği Bölümü, Samsun, \\ (ORCID: 0000-0002-9676-8377) \\ 2DSİ 7. Bölge Müdürlüğü, Planlama Şubesi, Samsun, (ORCID: 0000-0002-2478-2516)
}

(Alınıs / Received: 1.10.2017, Kabul / Accepted: 04.04.2018, Online Yayınlanma / Published Online: 15.09.2018)

\begin{abstract}
Anahtar Kelimeler Özet: Dünyada ve ülkemizde su kaynakları hızla kirlenmekte, Baraj,

Değirmendere, küresel ısınmaya bağlı olarak yağıș rejimleri değişkenlik Ekonomik Analiz, Rantabilite, Karadeniz Bölgesi. göstermekte ve artan nüfusa paralel olarak artan su ihtiyaçları sonucunda temiz suyun önemi günden güne artmaktadır. Önümüzdeki 20-30 yll içinde su fakiri bir ülke haline dönüşeceğimiz kaçınılmaz bir son olarak ortadadır. Buna bağlı olarak, akarsu havzalarında içme suyu, sulama, enerji üretimi gibi amaçlarla geliştirilen projelerin en uygun amaç doğrultusunda en çok faydayı verecek biçimde geliştirilmesi esastır. Yapılan çalışmada Türkiye'nin Karadeniz Bölgesinde Amasya İlinin Değirmendere Köyünde sulama ve içmesuyu amaçlı olarak yapılan Değirmendere Barajının planlama sonuçları irdelenmiştir. Çalışmada, planlama aşamasında ortaya seçenek olarak konulan ancak kabul görmeyen alternatifler planlanmış ve mevcut seçenek, ekonomik yönden kıyaslanmıştır. Bu optimizasyon çalışmasında Değirmendere baraj gövdesinin yükseltilerek sulama sahasının artırılması ile proje rantabilitesi arasındaki ilişki belirlenmiştir.
\end{abstract}

\section{Economic Analysis Between Irrigation Area and Dam Height at Amasya Değirmendere Dam}

\section{Keywords}

Dam,

Değirmendere,

Economic

Analysis,

Profitability,

Blacksea Region.

\begin{abstract}
In the world and in our country water resources are rapidly becoming polluted, and due to global warming the precipitation regimes also varies, and the importance of clean water as a result of increasing water needs in parallel with the increasing population increases day by day. In the next 20-30 years, inevitably our country will turn a water poor country. Consequently, it is essential to develop the water basin projects as
\end{abstract}


giving maximum benefit considering drinking water, irrigation, power generation purposes with the most appropriate aim. In the study, the planning results of Değirmendere Dam, which is developed for drinking water and irrigation purposes in Amasya at Turkey's Blacksea Region, were examined. The unacceptable alternatives which are considered as an option in the recent planning without detailed study, are examined in planning phase and compared with current option as economically. In this optimization study, the relationship between enhancing the irrigation area by increasing dam's height and the project's incomeexpense ratio is determined.

*Sorumlu yazar: asli.ulke@omu.edu.tr

\section{Giriş}

Su kaynakları geliştirme projelerinin ana öğesini oluşturan su, yaşamımızı çok çeşitli biçimlerde etkileyebilmektedir. $\mathrm{Bu}$ etkilerin kontrol altına alınması ya da düzenlenerek yararımız için kullanılması ise su kaynakları geliştirme projelerinin konusunu ve amacını oluşturmaktadır [1].

Bir taraftan hızla gelişen dünyanın değișen koşullarına paralel olarak su kaynaklarının çeşitli amaçlar için kullanımına yönelik talepler giderek artarken, diğer taraftan dünya kamuoyu doğal çevrenin temel unsurlarından biri olan su ile ilgili sorunlara daha duyarlı davranmaya başlamıştır. Bu duyarlılık, su kaynaklarının gelişimi ile doğrudan ve dolaylı olarak ilintili tüm faaliyetlerin sistematik bir şekilde yeniden gözden geçirilmesi ve iyileştirilmesine yönelik çabalar ve yaklaşımların son yllarda büyük önem kazanmasına yol açmıştır [2]. Bugün pek çok ülkede ve bölgede su kıtlığı yaşanmaktadır. Bu kıtlığın nedeni doğal hidrolojik koşullardan kaynaklanmakla beraber, temel neden su kullanımlarının artması, çeşitlenmesi ve kirlenmesidir [3].

Kitasal iklim karakteri gösteren ülkemizde, düzensiz bir akış rejimine sahip olan nehirlerimizde inşa edilecek depolama tesislerinde suyun düzenlenerek yaz aylarında sulamada kullanılması, tarımsal üretimin arttırılması bakımından büyük önem taşımaktadır [4]. Su kaynaklarının geliştirilmesinde tüm bunların yanı sıra sosyopolitik düşüncelere de yer vermek gerekmektedir.

Bir bölgede mevcut su kaynaklarının yer ve zaman içinde dağılımı su gereksiniminin yer ve zaman içindeki dağılımı ile çoğu zaman uyuşmadığından, gerekli düzenlemeyi sağlayabilmek amacıyla mühendislik çalışmaları yapılması gerekmektedir. Bu çalışmalar, fiziksel bileşenler (baraj, sulama sistemi, vb.) ve bunların işletilmesi yoluyla mevcut su kaynaklarının yer, zaman ve kalite açısından özelliklerini isteklere uyacak biçimde değiştirmeyi amaçlar [5]. Su kaynakları projelerinde optimum çözümün bulunması ile, su kaynağının hangi maksatlarla ve ne ölçüde kullanılacağı, bu sırada hangi tesislerin kurulmasının gerektiği ve bunların büyüklükleri de belirlenmiş olur [6].

Çalışmada Amasya ilinde Değirmendere köyünde yer alan Değirmendere Barajında (Şekil 1) farklı gövde yüksekliği seçeneklerinin ekonomik karşılaştırması yapılmaktadır. İçme suyu ve sulama amaçlı Değirmendere Barajı 140 l/sn içme suyu temini ve 242 hektar (Alternatif 1) arazinin sulanması amacıyla yapılmıştır. Tasarlanırken mevcut baraj yüksekliğinin 1,55 metre ve 5,99 metre 

Ekonomik Analizi

artırılmasına bağlı olarak sulama alanının sırasiyla 304 (Alternatif 2) ve 468 (Alternatif 3) hektara çıkarılması teklif edilmiş, ancak kabul görmediği için bu seçenekler çalışılmamıştır. Her üç alternatifi ekonomik olarak kıyaslayabilmek için 2 . ve 3 . alternatifler baraj olarak çalışılarak ekonomileri bulunmuştur. Ortaya konulan üç farklı baraj ekonomisi çalışmanın sonunda karşılaştııılmıştır. $\mathrm{Bu}$ optimizasyon çalışmasında Değirmendere baraj gövdesinin yükseltilerek sulama sahasının artırılması ile proje rantabilitesi arasındaki ilişki belirlenmiștir.

Ayrıca Değirmendere Barajının bulunduğu Kanlıdere havzasının yan havzasında bulunan kuru dere üzerinde yine Kanlıdere'den derivasyon yapılarak depolama yapması planlanan Duruca Göleti'nin sulama sahası ve yatırım değerleri göz önüne alınarak ekonomik karşılaştırmaya dâhil edilmiştir.

Su havzaları planlanırken, sulama, taşkın, enerji, içme suyu gibi faydalar yönünden ciddi bir etüt ve araştırmaya tabi tutulmall, ülke ekonomisine olan katkıları maliyet-fayda açısından değerlendirilerek en ekonomik çözüm tercih edilmelidir. $\mathrm{Bu}$ ekonomik çözümlere ait karşılaştırma çalışmada Tablo 2'de sunulmuştur.

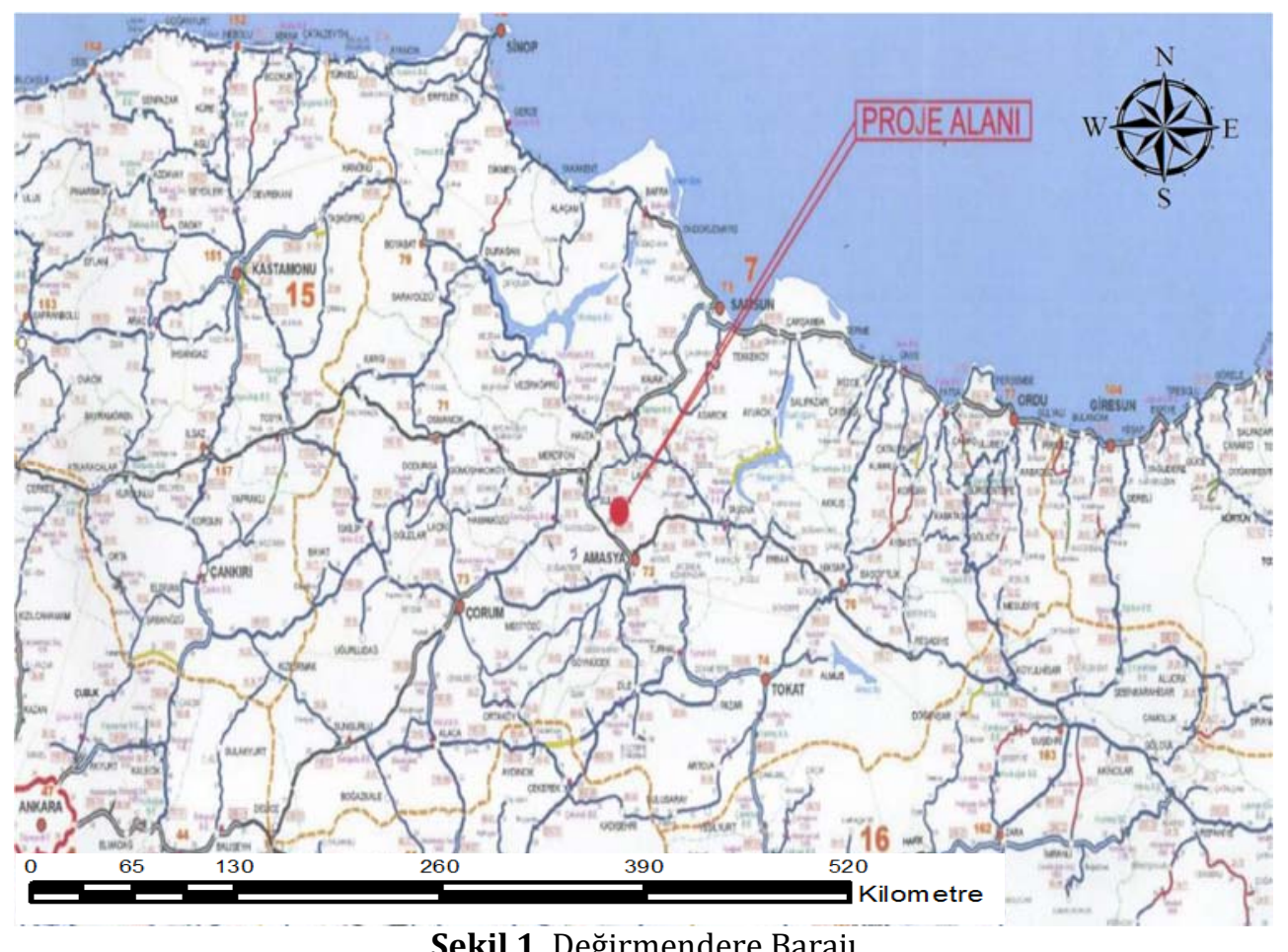

\section{Materyal ve Metot}

\subsection{Bir Barajın Planlaması}

Planlama, herhangi bir projenin teknik ve ekonomik yönden yapılabilirliğini araştırmak ve en uygun çözümü bulmaktır [7]. Planlamanın esası sinırlı kaynakların, öngörülen gayeleri azami kılacak şekilde paylaşılmasından ibarettir. Bu maksatla bütün imkânlar ve ihtiyaçlar detaylı bir şekilde etüt edilerek ortaya çıkarılmış olmalıdırlar. Ana veriler dediğimiz bu bilgilerin güvenirliği hazırlanacak plan ve programların uygulanabilir olması üzerinde en büyük rolü oynarlar [6]. Baraj planlamasının hedefi, teknik ve ekonomik açılardan en 
uygun baraj yeri, türü ve büyüklüğünün seçimi ile işletme çalışmasının belirlenmesidir. Planlama çalışmalarında, elenmeyen seçenekler daha ayrıntılı olarak hem teknik hem de ekonomik yönden incelenir. Barajın havza içindeki yeri, ana boyutları, maliyeti bu safhada belirlenir. Bu adım sonunda projenin teknik ve ekonomik yönden yapılabilirliği ortaya konur [8]. Ağıralioğlu'na göre (2004) bir baraj planlama raporunda şu bilgilerin bulunması gerekir: barajın minimum işletme kotu, normal su seviyesi, maksimum su seviyesi, malzeme envanteri ve özellikleri, sondaj logları ve değerlendirmeleri, temel ve yamaçların taşıma gücü ve sızdırmazlık özellikleri, baraj gölünün su tutma özelliklerini gösteren çalışmalar, baraj gölünün toprak kayma durumu bakımından tahkikleri, yörenin deprem durumu ve risk analizi, çevirme yapılarına esas olacak hidrograf, seviye-alan ve seviye-hacim eğrileri, çeşitli dönüş aralıklı taşkın hidrografları, su ihtiyaçları, mansap suyu anahtar eğrileri, mansap yatağının projeli durumda kapasitesi [8].

Su kaynaklarının geliştirilmesinde su, toprak, topoğrafya, jeoloji ve bunun gibi fiziki verilerin yanı sıra, kültürel, endüstrileşme, ekonomik, idari ve sosyal şartlara yönelik çok çeşitli bilgilere ihtiyaç bulunmaktadır.

\subsection{Değirmendere Barajı ile İlgili Teknik Bilgiler}

Barajın yer aldığı havza Şekil 1'den de görüldüğü gibi Orta Karadeniz Bölgesinde Amasya ili sınırları içerisinde bulunmaktadır. Havzada kıyı Karadeniz ılıman ikliminden iç kesimin kurak iklimine geçiş özelliklerini gösteren iklim karakteri hâkimdir. Yazları sıcak ve kurak, kışları soğuk ve yağıșlıdır. Yağışların en etkili olduğu dönem, kış ve ilkbahar aylarıdır.

Planlama kapsaminda sunulan revize planlama raporunda Suluova ilçesi,
Duruca, Boğazköy ve Fındıklı köylerine tahsis edilen $140 \mathrm{l} / \mathrm{s}$ içme suyunun yanı sıra; Değirmendere, Duruca (Lap) ve Yolpınar köylerine ait brüt 242 (Alternatif 1), 304(Alternatif 2) ve 468 (Alternatif 3) hektar tarım arazisinin sulanması düşünülmüştür. Tüm bu üç alternatiften 140 l/s içmesuyu temininin yanı sıra 242 ha arazinin sulanması alternatifi yapılabilir bulunmuş ve inşası yapılmıştır.

Projeye konu olan Değirmendere Barajı, Kanlıdere üzerinde inşa edilen kil çekirdekli zonlu dolgu tipinde, 319.02 metre kret uzunluğunda, temelden yüksekliği $52.70 \mathrm{~m}$, aktif hacmi $4.393 \mathrm{hm}^{3}$ ve gövde dolgu hacmi $1.568 \mathrm{hm}^{3}$ 'dir. Değirmendere Barajının yatırım bedeli ise 2009 yll birim fiyatlarına göre 27,963,163.00 TL, yıllık toplam geliri 3,285,496.00 TL, ylllk toplam gideri 1,744,134.00 TL olup, 140 l/sn içme suyu tahsisi ve 242 hektar tarımsal sulama ile birlikte rantabilitesi $1.88^{\prime}$ dir.

\subsection{Ekonomik Analiz Yöntemi}

Yapılan çalışmada ekonomik analiz yapmak için esas olarak projenin gelirgider oranı olan rantabilite değeri dikkate alınmıştır. Ayrıca gelir-gider farkı, geliryatırım oranı, projenin karlılık oranı, gelir artış oranı değerleri de proje hakkında değerlendirme yapılabilmesi amacıyla kullanılmıștır. İki veya daha fazla alternatiften birini seçmeye dayanan ekonomik yapılabilirliğe, ekonomik analiz veya fayda maliyet analizi de denir [9]. Değirmenci'ye göre (1990) en ekonomik çözüm, aynı zamanda yıllık gelir ve yıllık gider farkının en büyük olduğu çözümdür [7].

\subsubsection{Ekonomik Analizin Unsurları}

Tesis bedeli, keşif bedeli ve bilinmeyen giderlerin toplamı ekonomik analizin unsurlarını oluşturur. Bilinmeyen giderler olarak tesis maliyetinin \% 15'i alınabilir. Yatırım bedeli, proje bedeli ile inşaat süresi faizin toplamıdır. Proje bedeli ise tesis bedeli, etüt-proje ve 
kontrollük giderleri ve kamulaştırma giderlerinin toplamıdır. Etüd-proje ve kontrollük giderleri olarak, tesis bedelinin yine \% 15'i alınabilir. Kamulaştırma giderleri ise tarımsal ekonomistler tarafindan hesaplanır ve tarımsal ekonomi raporunda verilir. İşaat süresi faizi $\mathrm{F}$ ise Denklem 1'de verildiği gibi hesaplanır;

$$
F=\left[(1+i)^{N / 2}-1\right] * A
$$

Burada N, uygulama programında inşaat süresi (yıl); i, sosyal iskonto oranı ve A da proje bedelidir.

İşletme ve bakım giderleri, bu tesisin bakım, onarım ve işletilmesi için bir yıl içinde yapılan harcamaların toplamıdır. İşletme ve bakım faktörleri ile tesis bedelinin çarpımıyla elde edilir. Buna göre yenileme ve ișletme-bakım faktörleri Tablo 1'de verilmiştir.

Tablo 1. Yenileme ve ișletme faktörleri
Amortismansa, faiz ve yenileme giderleri ile projenin yatırım bedelinin yenileme giderleri dâhil geri ödenmesi için her yıl faizi ile birlikte geri ödenmesi gereken eşit taksitlerdir. Amortisman, faiz ve yenileme faktörü ile yatırım bedelinin çarpımı ile bulunur. Amortismanı veren formül de Denklem 2'de görüldüğü gibidir.

$$
a=\frac{c i *(i+1)^{n}}{(i+1)^{n}-1}+\frac{(1-c) * i *(i+1)^{N}}{(i+1)^{N}-1}
$$

Burada, c, \% cinsinden yenileme oranını; $\mathrm{i}$, Faiz oranı (sosyal iskonto oranı); $\mathrm{n}$ : yenileme süresi ve $\mathrm{N}$ : amortisman süresini vermektedir.

Toplam gider, işletme ve bakım gideri ile faiz amortisman, yenileme giderlerinin toplanması ile bulunur. Sosyal iskonto oranı, paranın ulusal ekonomi açısından yatırıma harcanmasına değer faiz oranıdır. Bu faiz oranı değișik amaçlı projeler için farklıdır. DSİ'de uygulanan sosyal sosyal iskonto oranları şu şekildedir; sulama amaçlı projeler için (pompaj sulamaları dahil) \% 5; enerji amaçlı projeler için \% 9,5; içme suyu temini amaçlı projeler için \% 8; taşkın koruma ve kurutma amaçlı projeler için \% 5.

\begin{tabular}{llllll}
\hline Tesisin Adı & $\begin{array}{l}\text { Yenileme } \\
\text { müddeti } \\
\text { (yıl) }\end{array}$ & $\begin{array}{l}\text { Yenileme } \\
\text { oranı } \\
\%\end{array}$ & $\begin{array}{l}\text { Yenileme } \\
\text { faktörü } \\
\text { (f=0.05 için) }\end{array}$ & $\begin{array}{l}\text { Yenileme } \\
\text { faktörü } \\
\text { (f=0.095 için) }\end{array}$ & $\begin{array}{l}\text { İşletme- } \\
\text { Bakım } \\
\text { faktörü }\end{array}$ \\
\hline Gövde & 45 & 2 & 0.000125 & 0.0000326 & 0.005 \\
\hline Dolusavak & 45 & 2 & 0.000125 & 0.0000326 & 0.01 \\
\hline Dipsavak & 45 & 2 & 0.000125 & 0.0000326 & 0.005 \\
\hline Ulaşım Yolu & 45 & 2 & 0.000125 & 0.0000326 & 0.04 \\
\hline Sosyal Tesis & 20 & 10 & 0.00302 & 0.0018480 & 0.01 \\
\hline $\begin{array}{l}\text { Derivasyon } \\
\text { Tüneli }\end{array}$ & 45 & 2 & 0.000125 & 0.0000326 & 0.050 \\
\hline Batardolar & 45 & 2 & 0.000125 & 0.0000326 & 0.005 \\
\hline Sulama Şebekesi & 45 & 2 & 0.000125 & 0.0000326 & 0.02 \\
\hline Çelik Boru & 45 & 50 & 0.00313 & 0.0008136 & 0.02 \\
\hline
\end{tabular}


Projelerin döviz ihtiyacını hesaplamakta belirli bir düzeni sağlamak amacıyla günümüzde DSİ'nin yaptırdı̆̆ı işlerin en önemlilerinin döviz ihtiyaçları, tesis bedelinin yüzdesi olarak verilir. Proje ünitelerinin tesis bedellerini bu yüzdelerle çarpmak suretiyle iç ve dış para ihtiyacı miktarları kolayca bulunabilmektedir [7].

Sulama geliri, projenin sulama alanında tarımsal ekonomistlerce yapılan çalışmalar sonucu hesaplanan dekar başına net gelir artışlarının net sulama alanı ile çarpılmasıyla bulunur. Projenin işletmeye açılmasından itibaren net gelir artışları gelişme süresi sonuna kadar her yıl artarak gelişme süresi sonunda maksimuma ulaşmak suretiyle işletmenin sonuna kadar aynı düzeyde devam eder [10].

Projenin gelişim süresi sonunda; projeli durumda dekar başına gelirin net proje alanı ile çarpımından, mevcut durumda dekar başına gelirin brüt alan ile çarpımının çıkarılmasıyla Yıllık Toplam Net Gelir elde edilir.

\subsection{Rantabilite}

Ekonomik analiz süresince bir projenin yıllık gelirinin yıllık giderine bölünmesidir. Elde edilecek oran 1 veya 1 'den büyük bir sayı ise proje ekonomik yönden savunabilir mahiyette olup, bu oran proje rantabilitesi olarak tanımlanır [10].

\subsection{Ekonomik Analize Yardımcı Diğer Faktörler}

Ekonomik analiz yapılırken esas olarak rantabilite değeri dikkate alınmakla birlikte; gelir gider farkı da göz önüne alınabilir. Gelir-gider farkı, yıllık toplam net gelirden ylllk toplam net giderin çıkarılması ile bulunur. Projenin yapılabilir olması için Gelir-gider farkının eksi değer olmaması esastır.

\section{Bulgular \\ 3.1. İncelenen Alternatifler}

Değirmendere Projesinin meteorolojik ve hidrolojik verileri 2000 ve 2007 yıllarında kuraklık görülmesi dolayısıyla revize edilmiş, su temin hesapları değiștiğinden dolayı sulanabilecek arazi miktarı 242 ha olarak güncellenmiştir. 2000 yılında onaylanmış olan daha önceki revize raporda da sulanacak arazi miktarı 468 ha olarak planlandığından ötürü, 2011 yılında hazırlanan revize raporda barajın yükseltilerek sulanacak arazinin artırılması üzerine alternatifler ortaya konulmuştur.

\subsubsection{Alternatif 1}

Değirmendere Barajının mevcut durumuyla Suluova ilçe merkezi ile Değirmendere, Duruca, Yolpınar, Boğazköy ve Findıklı köylerine 140 l/s içme suyunun temin edilmesi ile beraber Değirmendere ve Duruca köylerine ait brüt 242 ha arazinin sulanması düşünülmüş olup, en uygun alternatif olarak 2011 yılında bu seçenek kabul edilmiştir.

Projenin yıllık toplam geliri 3,285,496.00 TL, gideri $1,744,134.00$ TL olup, rantabilitesi 1.88 ve gelir-gider farkı 1,541,363.00 TL'dir [11].

\subsubsection{Alternatif 2}

Suluova ilçe merkezi ile Değirmendere, Duruca, Yolpınar, Boğazköy ve Fındıklı köylerine 140 l/s içmesuyu tahsisi yapılması ve Değirmendere, Duruca ve Yolpınar köylerine ait brüt 277 ha arazinin yanı sıra Suluova Sulaması ile su yetersizliği sebebiyle sulanamayan brüt 27 ha arazi de dahil olmak üzere toplam brüt 304 ha arazinin basınçlı sulama ile sulanması seçeneği incelenmiştir.

Projenin yıllık toplam geliri 3,590,112.00 TL, gideri $1,810,124.00$ TL olup, rantabilitesi 1.98 ve gelir-gider farkı 1,779,988.00 TL'dir [12]. 
$\mathrm{Bu}$ seçenekte inşaatına başlanmış olan Değirmendere Barajının $1.55 \mathrm{~m}$ yükseltilmesi gerektiği tespit edilmiştir. Ancak inşaat sürecinin başlayacak olması ve olası bir proje revizyonunun inşaat bitim süresini uzatacağı, maliyeti artıracağı gibi gerekçelerle bu seçenek değerlendirmeye alınmamıștır.

\subsubsection{Alternatif 3}

Suluova ilçe merkezi ile Değirmendere, Duruca, Yolpınar, Boğazköy ve Fındıklı köylerine $140 \mathrm{l} / \mathrm{s}$ içme suyu tahsisi yapılması ve Değirmendere, Duruca ve Yolpınar köylerine ait brüt 277 ha arazinin yanı sıra Suluova Sulaması ile su yetersizliği sebebiyle sulanamayan brüt 191 ha arazi de dahil olmak üzere toplam brüt 468 ha arazinin basınçlı sulama ile sulanması seçeneği incelenmiştir.

Ekonomik analizde brüt 468 hektar sulama alanı için 421.2 hektar net sulama alanı göz önüne alınmaktadır. Projenin yllık toplam net geliri 4,395,870.00 TL, gideri 2,033,634.00 TL olup, rantabilitesi 2.16 ve gelir-gider farkı 2,362,236.00 TL olmaktadır [12].
Bu seçenekte de; inşaatına başlanmış olan Değirmendere Barajının $5.99 \mathrm{~m}$ yükseltilmesi gerektiği tespit edilmiş ve 2 . Alternatifte belirtilen gerekçelerden ötürü uygulamaya geçirilmemiştir [11].

\section{Tartışma ve Sonuç}

Bu çalışmada, aynı havza üzerinde üç adet planlama düşünülmüștür. Tablo 2'de özeti verilen bu çalışmalar arasından ilgili yatırımcı kuruluş 1 . Alternatifi tercih etmiştir.

Araștırmanın amacı doğrultusunda, kabul edilmeyen 2 ve 3 . Alternatifler çalışılarak iki adet farklı yeni baraj gövdesi tasarlanarak metraj, keşif ve yatırım miktarları hesap edilmiştir. Buna dayanarak her üç alternatif için elde edilen verilere göre rantabilite ve gelirgider farkı parametreleri Tablo 2'de karşılaştırma amacı ile gösterilmiştir.

Yapılan karşılaştırmadan da görüleceği gibi bu çalışmada barajın yüksekliği artırıldıkça, ekonomik kriterler olumlu yönde değişmektedir.

Tablo 2. Alternatiflerin Karşılaştırılması

\begin{tabular}{|c|c|c|c|}
\hline & 1. Alternatif & 2. Alternatif & 3. Alternatif \\
\hline & $\begin{array}{l}140 \text { l/sn içme suyu } \\
+ \\
242 \text { ha sulama }\end{array}$ & $\begin{array}{l}140 \text { l/sn içme suyu } \\
+ \\
304 \text { ha sulama }\end{array}$ & $\begin{array}{l}140 \text { l/sn içme suyu } \\
+ \\
468 \text { ha sulama }\end{array}$ \\
\hline Önerilen kret kotu (m) & 572.70 & 574.25 & 578.70 \\
\hline Talvegden yükseklik (m) & 49.70 & 51.25 & 55.70 \\
\hline Gövde dolgu hacmi $\left(\mathrm{hm}^{3}\right)$ & 1.568 & 1.674 & 2.043 \\
\hline $\begin{array}{l}\text { Baraj ve tesisleri keşif bedeli } \\
\text { (TL) }\end{array}$ & $13,000,147.00$ & $13,439,869.00$ & $15,377,392.00$ \\
\hline $\begin{array}{l}\text { Sulama tesisleri keşif bedeli } \\
\text { (TL) }\end{array}$ & $1,500,961.00$ & $1,800,072.00$ & $2,427,278.00$ \\
\hline Proje yatırım bedeli (TL) & $27,963,163.00$ & $28,994,194.00$ & $32,601,093.00$ \\
\hline Sulama net geliri (TL) & $1,188,984.00$ & $1,493,600.00$ & $2,299,358.00$ \\
\hline Yıllık toplam net gelir (TL) & $3,285,496.00$ & $3,590,112.00$ & $4,395,870.00$ \\
\hline Yıllık toplam gider (TL) & $1,744,134.00$ & $1,810,124.00$ & $2,033,634.00$ \\
\hline Rantabilite & 1.88 & 1.98 & 2.16 \\
\hline Gelir gider farkı & $1,541,363.00$ & $1,779,988.00$ & $2,362,236.00$ \\
\hline
\end{tabular}


Rantabilite mevcut durumda 1.88 iken; sulama alanı 304 hektar olacak şekilde planlama yapıldığında 1.98 olmakta, 468 hektar alan sulanacak şekilde yapıldığında ise 2.16'ya yükselmektedir. Eğer rantabilite 1'den büyük çlkarsa projenin geliri giderinden fazla olduğundan gerçekleştirilmesi uygun olarak kabul edilmektedir [7].

Her üç alternatif için Gelir Gider Farkına bakıldığında mevcutta 1,541,362.00 TL'den, 304 hektar sulama alanı için 1,779,988.00 TL'ye, 468 hektar sulama alanı için ise 2,362,236.00 TL'ye çlkmaktadır.

Tablo 2'deki yatırım bedelleri kıyaslandığında; 1 . alternatifte inşa edilen 49.70 metre yüksekliğindeki baraj ile 242 hektar alanın sulama sisteminin yatırım bedeli 27,963,163.00 TL'ye, 2 . alternatifte düșünülen 51.25 metre yüksekliğindeki baraj ile 304 hektar alanın sulama sisteminin yatırım bedelininse 28,994,194.00 TL'ye mal olduğu görülmektedir. 3. alternatifte düşünülen 55.70 metre yüksekliğindeki baraj ile 468 hektar alanın sulama sisteminin yatırım bedeli $32,601,093.00$ TL olmaktadır.

Sulama sahası 242 hektardan 468 hektara çlkarken, sulama net gelirindeki artış \% 93'e çıkmakta, yatırım miktarındaki artış oranı ise sadece \% 16 olmaktadır. Dolayısı ile yatırım miktarında cüzi bir artış ile sulanan arazi miktarını ve tarımsal geliri ciddi bir oranda artırma imkânı doğmaktadır. Yani yatırım miktarındaki \% 16'lık artışa karşılık, sulama net gelirinde \% 93 artış sağlanmaktadır.

Günümüz koşullarında, Değirmendere Barajı Sulamasının 242 hektar ile sinırlı kalması sebebiyle projenin yan havzasında Duruca Göleti ve Sulaması Projesi geliştirilmiştir. $\mathrm{Bu}$ göletten üzerinde bulunduğu Çilligin deresinden gelecek yıllı 178,000 $\mathrm{m}^{3}$ su ile Değirmendere Barajının membasından derive edilecek yıllık 281,500 $\mathrm{m}^{3}$ suyun depolanarak 111 hektar sahada sulama yapılması planlanmıştır. $\mathrm{Bu}$ Projenin yatırım bedeli 9,599,086.00 TL'dir. 242 hektar tarım sahasını sulayan ve 140 l/sn de içme suyu tahsisi bulunan Değirmendere Barajının sulama alanını 226 hektar artırmanın maliyeti yatırım bedeli 4,637,930.00 TL olacak iken, 111 hektar saha için yatırım bedeli 9,599,086.00 TL olan Duruca Göleti Projesi geliştirilmiștir. Neredeyse yarısı kadar bir alan tam 2 katı maliyetine projelendirilmiştir.

Şekil 2' den görüldüğü üzere Duruca Göleti konum olarak Değirmendere Barajının hemen yakınında bulunmakta, sulama olarak Değirmendere Barajının sulayamadığı bitişik sahaları sulamaktadır [12].

Anlaşılacağı üzere, Değirmendere Barajının yükseltilerek sulama alanının artırılması kabul görmemiş, ancak daha sonra Değirmendere Barajının sulayabileceği alandan daha az bir sahayı sulamak için Duruca Göleti Projesi geliştirilmiştir. $\mathrm{Bu}$ örnek, planlama çalışmasında optimizasyon yapmak yoluyla alternatifleri değerlendirmenin önemini göstermektedir.

Değirmendere Barajının planlanmasında sunulan çeşitli rantabilitedeki seçenekler arasından mevcut baraj yüksekliğinin muhafaza edilmesine karar verilmesi sonucunda yeni bir gölet ihtiyacı ve yeni bir maliyet ortaya çlkmıştır. Değirmendere Barajının sulama alanlarını cüzi maliyet artışıyla seçenekli olarak; 62 hektar ve 226 hektar artırabilmek mümkün iken, aynı alandaki 111 hektar sahayı sulayabilmek için daha fazla mali gider sağlayarak Duruca Göleti adında yeni bir proje geliştirilmesi ekonomik olmamıștır. 


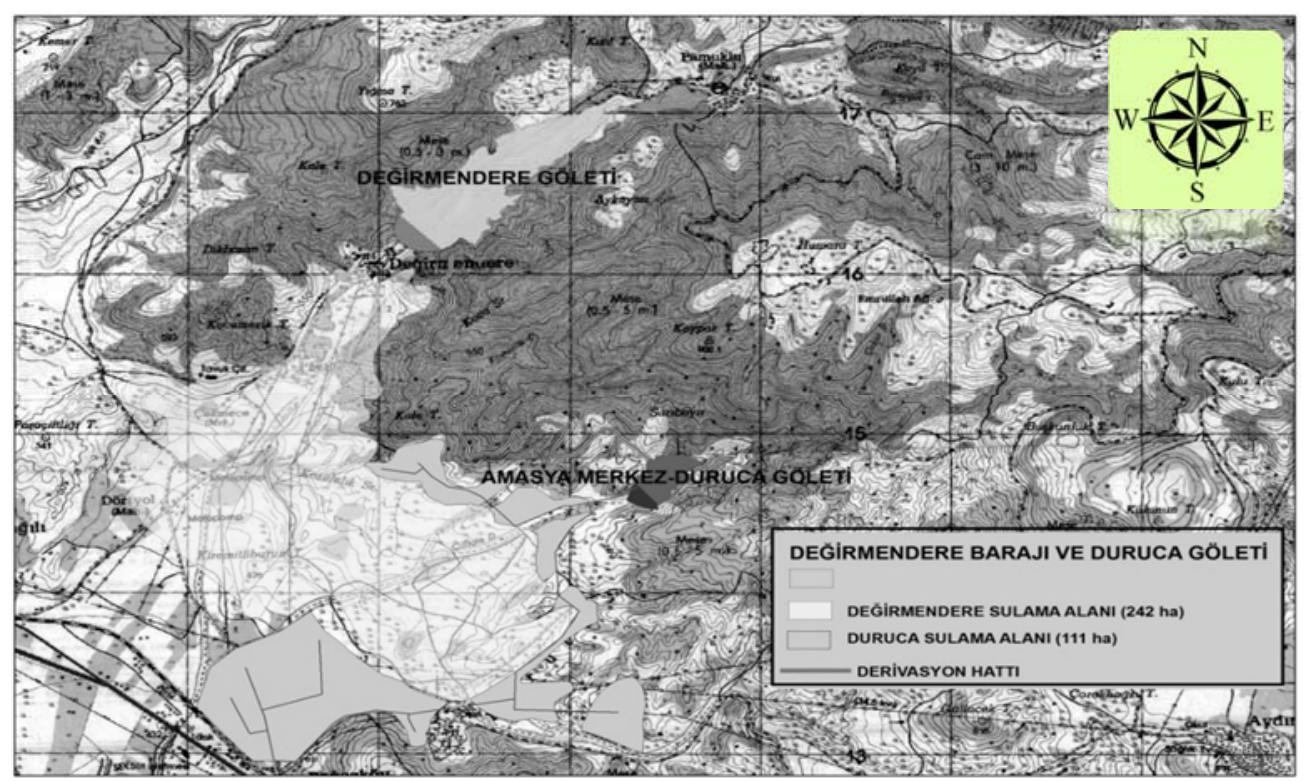

Şekil 2. Değirmendere Barajı ve Duruca Göleti Sulamaları

Sonuç olarak bir su yapısı yatırımının ekonomik ömrünün 50 yll olduğu düşünüldüğünde; planlama karar aşamasında siyasi vb. durumlar göz ardı edilerek optimum seçeneğe karar verilmesi ile ülkemizin kıt kaynaklarının israf edilmesinin önüne geçilmiş olacaktır.

\section{Kaynakça}

[1] Sezginer, Y., Güner, R., 1994. Su Kaynakları Geliştirme Projelerinin Gerçekleştirilmesinde

Uyumsuzluk Sorunlarl. T.C. Bayındırlık ve İskan Bakanlığı, DSİ Genel Müdürlüğü, 40'ıncı Kuruluş Yllı (1954-1994) Su ve Toprak Kaynaklarının Geliştirilmesi Konferansı Bildirileri, 12-14 Nisan 1994, Ankara, Cilt. 1, s.123-138.

[2] Kulga, D., 1994. Su Kaynakları Yönetiminde Dünyadaki Yeni Gelişmeler ve Türkiyedeki Durum. T.C. Bayındırlık ve İskan Bakanlığı,

[3] DSİ Genel Müdürlüğü 40'ıncl Kuruluş Yılı (1954-1994) Su ve Toprak

Kaynaklarının
Geliștirilmesi Konferansı Bildirileri, 12-14 Nisan 1994, Ankara, Cilt 1, s. 93-106.

[4] Berkün, M. 2005. Su Kaynakları Mühendisliği, Birsen Yayınevi, İstanbul, Türkiye, 439s.

[5] Bozkurt, S. ve Çakmak, C. (1994). Türkiye'de Sulama Projelerinin Gelişimi ve Bu Gelişimde DSİ'nin Rolü. T.C. Bayındırlık ve İskan Bakanlığı, DSİ Genel Müdürlüğü, 40'ıncı Kuruluş Yılı (1954-1994) $\mathrm{Su}$ ve Toprak Kaynaklarının Geliştirilmesi Konferansı Bildirileri, 12-14 Nisan 1994, Ankara, Cilt. 1, s.107-122.

[6] Berkün, M. 2007. Su Yapıları: Barajlar, Savaklar ve Su Kuvveti Tesisleri Mühendisliği, Birsen Yayınevi, İstanbul, Türkiye, 667s.

[7] Karataban, A.Y. 1976. Su Kaynaklarının Planlama ve İdaresinde Ekonomik ve Mali Fizibilite, DSİ Genel Müdürlüğü Matbaası, Ankara, Türkiye, 90s. 
A. Ü. Keskin ve Ș.D.Demir / Amasya Değirmendere Barajında Sulama Alanı ve Baraj Yüksekliği Arasında Ekonomik Analizi

[8] Değirmenci, İ., 1990. Su Ve Toprak Kaynakları Planlaması, Yeniçă̆, DSİ Genel Müdürlüğü Matbaası, Ankara, Türkiye, $195 \mathrm{~s}$.

[9] Ağıralioğlu, N., 2004. Baraj Planlama ve Tasarımı Cilt 1 . Su Vakfı Yayınları, İstanbul, Türkiye, 246s.

[10] Erkek, C. ve Ağıralioğlu, N., 1998. Su Kaynakları Mühendisliği, Beta Yayınları, 3. Baskı, İstanbul, Türkiye, 360s.

[11] Sarıslan H., 2014. Yatırım Projelerinin Hazırlanması ve Değerlendirilmesi: Planlama, Analiz, Fizibilite, Siyasal Kitabevi, Ankara, Türkiye, 448s.

[12] Demir, Ş.D. (2011). Amasya Değirmendere Barajı ve Sulaması Revize Planlama Raporu, DSİ, Samsun, Türkiye.

[13] Demir, Ş.D., 2015. Değirmendere Barajında Ekonomik Analiz, Ondokuz Mayıs Üniversitesi, Fen Bilimleri Enstitüsü, Yüksek Lisans Tezi, 147s, Samsun. 